\title{
Nitrogen Dynamics and Nutrient Budgets in Four Orchard Groundcover Management Systems
}

\author{
Amaya Atucha ${ }^{1}$ and Ian A. Merwin \\ Department of Horticulture, Cornell University, 134A Plant Science \\ Building, Ithaca, NY 14853
}

Chandra K. Purohit

SunArc Technologies, Sutharon Ki Bari Guwar, Bikaner, Rajasthan, India 334005

\section{Michael G. Brown \\ Department of Horticulture, Cornell University, $134 \mathrm{~A}$ Plant Science Building, Ithaca, NY 14853}

Additional index words. soil management, orchard sustainability, nutrient cycling, nitrate leaching, nitrate runoff

\begin{abstract}
Excessive nitrogen (N) applications can increase surface and water contamination, and leaching losses may occur when $\mathrm{N}$ fertilizer rates are too high relative to crop demands and soil $\mathbf{N}$ availability. Quantifying nutrient inputs, cycling, and outputs from orchards provides a method to measure surplus of nutrients, particularly $\mathrm{N}$, that may leach or runoff. We conducted a long-term study to develop $\mathrm{N}$ budgets based on observed nutrient dynamics under four groundcover management systems (GMSs) with and without $\mathbf{N}$ fertilization. Four GMS treatments were randomly assigned to 12 plots and maintained since 1992 in 2-m-wide strips within tree rows: pre-emergence residual herbicide (PreHerb), post-emergence herbicide (PostHerb), mowed-sod (Sod), and hardwood bark mulch (Mulch). We measured system $\mathbf{N}$ inputs in fertilizer, mulch biomass, rain, and irrigation water; $\mathrm{N}$ outputs in harvested fruit, surface runoff, and subsurface leaching; and internal $\mathbf{N}$ cycling from surface vegetation, soil mineralization, leaf fall, and pruned wood. For the year with $N$ fertilizer (2005), the overall $N$ balance was positive (inputs exceeded outputs) in all GMSs but greater in the PostHerb and Mulch treatments. In the year without $\mathrm{N}$ fertilizer (2007), the overall $\mathrm{N}$ balance was negative for PreHerb and PostHerb and positive for Mulch and Sod treatments. Soil mineralization and recycling groundcover biomass accounted for greater than $60 \%$ of internal $\mathrm{N}$ fluxes, and harvested fruit represented greater than $70 \%$ of $N$ outputs from the system during both years. During the year with $N$ fertilizer, $N$ losses were $1 \%$ to $4 \%$ and $18 \%$ to $22 \%$ through surface runoff and subsurface leaching, respectively. During the year without fertilizer, surface runoff $N$ losses were twice the subsurface leaching $N$ losses in all GMSs.
\end{abstract}

Intensive use of pesticides and fertilizers to obtain higher crop yields has increased surface and groundwater contamination by agrochemicals, and both economic and regulatory factors are driving growers to adopt more sustainable practices. Estimating nutrient fluxes and requirements under different orchard systems is essential to produce high yields of marketable fruit while minimizing the loss of fertilizer in leaching or runoff and subsequent environmental contamination. Where nutrient inputs, recycling pools, and outputs from the crop-soil system are quantified, the retention or transfers of nutrients from one system component to another can be budgeted on a yearround basis (Haynes, 1988; Palmer and Dryden, 2006). Nutrient budgeting is a useful tool for optimizing fertilizer programs in orchards,

Received for publication 25 Mar. 2011. Accepted for publication 25 June 2011.

${ }^{1}$ To whom reprint requests should be addressed; e-mailafa29@cornell.edu. but there are few published reports on this topic (Tagliavini et al., 1996). Overfertilization can cause nutrient imbalances in fruit trees and may adversely affect productivity and fruit quality. High $\mathrm{N}$ supply during fruit ripening may depress red color development (Wargo et al., 2004), delay ripening, and induce vegetative growth late in the growing season, making trees more susceptible to winter cold damage (Haynes, 1980). Oversupply of $\mathrm{N}$ can also cause excessive vegetative growth that increases self-shading within the tree canopy, reducing flower bud development, fruit set, and fruit quality (Weinbaum et al., 1992).

Nitrogen fertilizer that is not taken up by plants or soil organisms is prone to leaching or runoff, and such losses are more likely when $\mathrm{N}$ fertilizer inputs are not adjusted for crop demand and $\mathrm{N}$ availability in soil (Tagliavini et al., 1996). Quantifying nutrient inputs and outputs from orchards helps to identify potential nutrient excess or shortage (Watson and Atkinson, 1999), particularly for $\mathrm{N}$ because it is most often limiting in orchard soils, is prone to leaching, and is often applied in relatively large quantities as fertilizer (Weinbaum et al., 1992).

Amounts of $\mathrm{N}$ leaching and runoff have not been extensively quantified for orchards but reportedly vary as a result of differences in soil type and topography, rainfall, irrigation, fertilizer rates, mineralization and retention rates, microbial $\mathrm{N}$ immobilization, and soil or groundcover management (Haynes, 1988; Merwin, 2003a; Merwin et al., 1996). A seasonal pattern of nitrate-N losses through leaching has been observed in fertilized orchards with higher $\mathrm{N}$ losses during times of year when rainfall exceeds evapotranspiration (Ventura et al., 2005). Annual N-leaching losses of $50 \mathrm{~kg} \mathrm{~N} /$ ha have been reported - amounts sufficiently high to cause problems with groundwater contamination (Rossi et al., 1991).

Nitrogen removal with harvested crop biomass depends on crop yields and fruit nutrient content (Smith et al., 1988) and can range from 0.7 to $2.4 \mathrm{~kg} \mathrm{~N}$ per ton of fruit produced per season in apple and avocado trees, respectively (Stassen et al., 2010). Other $\mathrm{N}$ losses from leaf drop and prunings are reportedly minor and may be recycled in situ through mowing and brush grinding (Palmer and Dryden, 2006). Nitrogen recycling through groundcover clippings is reportedly large in comparison with leaf fall from fruit trees (Haynes, 1988). The groundcover vegetation itself takes up and retains most of the $\mathrm{N}$ released by its mowing, making it relatively unavailable to fruit trees but also reducing potential $\mathrm{N}$ losses through leachate (Haynes and Goh, 1980b).

Internal $\mathrm{N}$ cycling from $\mathrm{N}$ reserves within deciduous fruit trees has been estimated at $45 \%$ of the total amount required for annual growth in pear (Pyrus communis L.) trees and $50 \%$ for almonds (Prunus amygdalus L.) (Millard, 1995). Because of the relatively high contributions from internal cycling to total $\mathrm{N}$ requirements, many deciduous orchards show little response to $\mathrm{N}$ fertilizer applications. In the absence of competition from weeds, mineralization of soil organic matter and atmospheric deposition may provide enough $\mathrm{N}$ for established fruit trees (Greenham, 1980; Stiles and Reid, 1991).

Although there is little published information in this regard, nutrient availability, recycling, and losses probably vary among different orchard GMSs (Merwin and Stiles, 1994; Merwin et al., 1994, 1996). N mineralization is greater in soil environments favorable to this microbial process, which releases plant-available $\mathrm{N}$ forms from soil organic matter (Haynes, 1980). Soil organic matter (SOM) content is generally higher in GMSs that include mulches, year-round groundcover, or surface vegetation during part of the year (Hogue and Neilsen, 1987; Merwin, 2003a). SOM promotes $\mathrm{N}$ mineralization by increasing soil microbial biomass and activity (Yao et al., 2005), ultimately releasing nutrients to tree roots (Hogue and Neilsen, 1987). The $\mathrm{N}$ recycling in soils under clean cultivation or continuous use of soil-active herbicides is reportedly lower than that under 
groundcovers, because of decreased return and incorporation of plant residues to the soil in weed-free orchards, compared with GMSs such as mulches and mowed grass covers (Hogue and Neilsen, 1987; Merwin, 2003b).

Differences in nutrient budgets would be expected among orchard GMSs because nutrient inputs, and presumably outputs, differ among the various systems. These differences could be important for fertilization programs and should be considered to avoid overfertilization. Despite the established relationship between soil nutrient availability and groundcover or soil management, there have been few long-term studies measuring the impact of GMSs on orchard nutrient budgets. The present study was intended to compare the impacts of GMSs and $\mathrm{N}$ or phosphorus $(\mathrm{P})$ fertilization on nutrient retention and fluxes in an apple orchard. Our objective was to quantify the major inputs and outputs of $\mathrm{N}$ in an orchard after many years under four different GMSs with and without $\mathrm{N}$ and $\mathrm{P}$ fertilizer applications. The main hypotheses of this experiment were: 1) the four GMSs would cause different amounts of leaching and runoff with different concentrations and effluxes of $\mathrm{N}$ and $P$ in the experimental orchard; 2) surface vegetation and soil moisture content differences among the four GMSs would lead to different decomposition and $\mathrm{N}$ mineralization amounts; and 3) different tree growth and crop yield patterns among the GMSs - interacting with the soil and hydraulic processes described in the first two hypotheses-would lead to different optimal $\mathrm{N}$ budgets for trees in each GMS.

\section{Material and Methods}

Experimental site. The experimental site was a 0.8-ha, 17-year-old orchard located on the east side of Cayuga Lake near Ithaca, NY (lat. $42^{\circ} 49^{\prime} \mathrm{N}$, long. $76^{\circ} 49^{\prime} \mathrm{W}$; annual mean precipitation $76 \mathrm{~cm}$ ). The soil at this site is an Ovid glacial till, silty clay loam (mixed mesic Glosaquic Hapludalf) that was prepared for planting in 1991 by removing a previous old apple orchard and installing a replicated subsoil grid of 12 drainage lysimeters. After the site was limed, ploughed, and cultivated thoroughly, red fescue (Festuca rubra) turfgrass was sown in May 1991 throughout the area to be planted. Apple trees ('Empire' on 'M.9'/'MM.111' interstem rootstocks) were planted in April 1992 at $3 \times 6-\mathrm{m}$ spacing. Four GMS treatments were established in 2-m-wide strips within the tree rows and have been maintained since 1992. These GMS treatments were assigned randomly to 12 plots in April 1992 with three replicates of each treatment. Each experimental plot was $9 \mathrm{~m}$ wide across the slope and $25 \mathrm{~m}$ long downslope, including four parallel tree rows containing 20 to 24 trees each and separated by $4-\mathrm{m}$ wide turfgrass drive lanes (Merwin et al., 1996).

Groundcover management system treatments. The four GMS treatments were: 1) PreHerb: a pre-emergence residual herbicide treatment consisting of three herbicides (glyphosate, norflurazon, and diuron) tankmixed at $2.0,3.0$, and $2.5 \mathrm{~kg}$ a.i./ha, respectively, applied in mid-May each year; 2) PostHerb: a post-emergence herbicide treatment consisting of glyphosate applied at a rate of $2 \mathrm{~kg}$ a.i./ha in mid-May and July each year; 3) Mowed Sod: a red fescue (Festuca rubra L) turfgrass originally seeded in 1991 that eventually comprised a mixture of various grass and broadleaf species, mowed monthly during the growing season each year; and 4) Mulch: a $15-\mathrm{cm}$ thick layer of partially composted (4 to 6 months of thermocomposting before applications) shredded hardwood bark mulch (a mixture of Acer, Quercus, Juglans, Fraxinus, and Tilia sp.) applied in 1992, 1995, 1998, 2000, 2002, and 2005. Mulch was applied at a rate of $27 \mathrm{~kg} \cdot \mathrm{m}^{-2}$ and the $\mathrm{N}$ content (dry weight) of the bark mulch material averaged $0.47 \%$. Glyphosate herbicide was spot-applied to the Mulch plots in mid-May annually from 1996 onward to suppress emergent perennial weeds (Oliveira and Merwin, 2001; Yao et al., 2005).

Orchard management. Soil and tree nutrient content have been analyzed annually since 1992, and for the present study, we monitored nutrient dynamics in a year with $\mathrm{N}$ and $\mathrm{P}$ fertilizer additions (2005) and another year without ground-applied fertilizers (2007). Trees were fertilized in May 2005 applying ammonium nitrate $(34 \mathrm{~N}-0 \mathrm{P}-0 \mathrm{~K})$ at a rate of $318 \mathrm{~g} /$ tree equivalent to $0.108 \mathrm{~kg} \mathrm{~N} /$ tree and $60 \mathrm{~kg} \mathrm{~N} / \mathrm{ha}-\mathrm{a}$ typical $\mathrm{N}$ amount for apple trees of this age and size in commercial NY orchards. Routine fertilizer P applications for mature apple trees are not recommended in NY orchards (Stiles and Reid, 1991), but to test for differential GMS effects on P leaching, we applied $22.7 \mathrm{~kg}$ of superphosphate $(0 \mathrm{~N}-45 \mathrm{P}-$ $0 \mathrm{~K})$ as a side dress soil application beneath trees in May 2005. During the next years (2006, 2007, and 2008) no N or P fertilizers were applied beneath trees in this study.

Subsurface drainage and surface runoff sampling system. In 1991, a subsoil drainage system with a replicated grid of perforated polyvinyl chloride (PVC) drainage lines was installed beneath the experimental plots. These 12 independent subsurface drainage lines intercepted leachate from four contiguous tree rows that comprised each GMS treatment replicate. All the plots were hydrologically isolated from each other by installing perimeter drainage interception lines at $0.8-\mathrm{m}$ depth in 6 -m-wide surrounding buffer zones. A single perforated PVC line was installed at $0.7-\mathrm{m}$ depth down the center of each GMS plot, draining to the downslope edge of each treatment area, and then coupled through solid (non-perforated) PVC pipes to a belowground collection station where subsurface leachate from individual plots was collected for analyses. The approximate drainage interception area for each sampling station was $48 \mathrm{~m}^{2}$ representing a 2-m-wide swath lengthwise above the subsoil drainage line transecting each GMS plot.

Surface runoff was measured with tipping buckets at the lower edge of a $6-\mathrm{m}^{2}$ area within one tree row of each GMS plot. A microsprinkler irrigation system, capable of delivering $32 \mathrm{~L} \cdot \mathrm{h}^{-1}$ of water over the GMS treatment area beneath each tree, provided irrigation and facilitated water sample collection when there were prolonged dry periods. To collect water samples for chemical analyses, a 2-mm-diameter hole was bored above a small dam in each drainage outfall pipe to divert some outflowing water into sample bottles suspended beneath the collection pipe. For each outflow collection site, a tipping bucket was attached with a batteryoperated Hobo-8 data logger (Onset Technologies, Bourne, MA) to record the number of tips. These calibrated tipping buckets measured continuous outflow of water from each plot in both subsurface drainage and surface runoff systems: multiplying the number of tips with the calibrated value of each tipping bucket to estimate total outflows (Brown, 2005). Water flow in subsurface leaching and surface runoff was measured from Mar. to Nov. 2005 during the first (fertilized) phase of this study and from May 2007 to Apr. 2008 during the second (unfertilized) phase. Nutrient concentrations in subsurface leachate and surface runoff were measured periodically (whenever the sample bottles were full) during those same two observation periods.

Nutrient budgets were constructed using the entire data sets from both years of the study. For comparing mean values in 2005 versus 2007, the flow volumes and $\mathrm{N}$ and $\mathrm{P}$ concentrations in water samples were calculated and compared for equivalent time periods each year. Estimated $\mathrm{N}$ and $\mathrm{P}$ losses per hectare were calculated based on the data for each year adjusted because each GMS treatment area represented one-third of the total orchard floor area (only the tree rows), whereas the other two-thirds was covered with turfgrass drive lanes that were the same for all GMSs throughout the site.

Fruit yield and nutrient analyses. Fruit yield was recorded from 1994 onward, as harvested fruit (kilograms) per tree, fruit counts, fruit size (grams), and total yield per tree (harvested + dropped fruit in $\mathrm{kg} /$ tree). Fruit yield data were collected separately for each tree and then averaged to provide a treatment mean for each GMS replicate. During harvest in 2005 and 2007, a random sample of 10 apples per plot was selected for total $\mathrm{N}$ analysis. Two slices from opposite sides of each fruit were oven dried at $70^{\circ} \mathrm{C}$ over several days to constant weight and sent to the Cornell Nutrient Analysis Laboratory (CNAL, Ithaca, $\mathrm{NY}$ ) to determine carbon (C) and N content by Dumas combustion. To calculate total $\mathrm{N}$ exported in fruit, the average yield for each study year was multiplied by the percentage of $\mathrm{N}$ and total amount of fruit harvested that year within each plot and extrapolated to 1 ha (555 trees).

Total nitrogen in leaf biomass and pruned wood. To determine the amount of $\mathrm{N}$ recycling from leaf drop, one representative tree in each plot was completely wrapped with nylon netting in early fall to catch all of its leaves as they abscised. When leaf drop was complete, leaves were collected and oven-dried 
to a constant weight at $70{ }^{\circ} \mathrm{C}$ over several days. Dry weights of these samples were recorded and then multiplied by $\mathrm{N}$ leaf content (measured as mentioned previously for fruit samples) for 2005 and 2007, respectively. During the Winters of 2001 and 2009, all of the wood trimmings were collected after pruning two trees in each plot, oven-dried to constant weight, and analyzed for total $\mathrm{N}$ by Dumas combustion. Values of total $\mathrm{N}$ recycling from pruned wood during 2001 were used to estimate $\mathrm{N}$ budgets for 2005 , and values from 2009 were used to estimate N budgets for 2007 each GMS.

Litter collection and litter bag preparation for residue decomposition study. During the 2005 and 2007 growing seasons, a litter decomposition study was carried out using chopped surface vegetation from each GMS and placing it into nylon mesh bags. The initial litter samples were collected on June 2005 and May 2007 from a randomly selected $1-\mathrm{m}^{2}$ area within the 2-m wide GMS treatment strip of each plot. A quadrangle frame $\left(1 \mathrm{~m}^{2}\right)$ was thrown into the $2-\mathrm{m}$ wide treatment strips at randomly selected sites, and the aboveground biomass of surface vegetation within each sample quadrant was severed at the soil surface and collected in paper bags.

From each plot, an average of $1.0 \mathrm{~kg}$ fresh weight of litter sample was collected, taken to the laboratory, and oven-dried at $70{ }^{\circ} \mathrm{C}$ over several days to constant dry weight. In 2005, three nylon mesh bags of $24 \times 24 \mathrm{~cm}(2-\mathrm{mm}$ mesh) were used for each plot with an initial $50 \mathrm{~g}$ of oven-dried litter sample in each mesh bag. In 2007, groundcover litter samples were sorted into four categories: apple leaves, grasses, legumes, and other broadleaf species. Five nylon mesh bags of $20 \times 40-\mathrm{cm}$ dimension were used for each plot as replicates over time with an initial $40 \mathrm{~g}$ of oven-dried litter sample in each mesh bag. For sequential sampling, each treatment replicate had a set of five bags containing a representative proportion of apple leaves, legumes, grasses, and broadleaf species collected from the respective plots.

For both years of this study, before the field decomposition tests, one litter bag per plot was measured for total $\mathrm{C}$ and $\mathrm{N}$ by Dumas combustion (C-to-N of initial litter samples). To estimate decomposition and $\mathrm{N}$ mineralization rates in the orchard, the litter sample mesh bags were placed midpoint between trees within each plot in the tree row. Soil surface vegetation was removed at the mesh bag placement site to allow contact of the mesh bags with the soil at each decomposition site. To keep mesh litter bags in place, a black plastic screen was placed over them and pinned to the soil surface at each corner.

One bag from each plot was removed without disturbing the surrounding bags at monthly intervals from Aug. to Oct. 2005 and at 6-week intervals from June to Oct. 2007. After each removal, the litter sample remnants were placed into paper bags so that no material was lost during transportation to the laboratory for processing. The litter samples were then weighed to obtain fresh weights and oven-dried to a constant weight at $70{ }^{\circ} \mathrm{C}$ over several days. Dry weights of the samples were recorded, and total $\mathrm{C}$ and $\mathrm{N}$ content of the remaining litter residues was measured by Dumas combustion. Based on C-to-N ratios and dry weight of the remaining litter mass at three removal dates, we calculated the percentage of decomposed litter mass at each removal date, $\mathrm{N}$ mineralization rate, and quantity of $\mathrm{N}$ released per kilogram of litter from each GMS treatment.

The percentage of the initial litter mass remaining (PLR) was calculated as litter biomass remaining at each removal date based on the initial litter mass recorded at the start of the study using the following equation: $\begin{aligned} \text { PLR }= & {[(\text { Initial wt }- \text { Final wt }) / \text { Initial wt }] } \\ & \times 100\end{aligned}$

Eq.[1]

For calculating $\mathrm{N}$ mineralization rate, first we calculated the difference in dry weight for the three removal times:

$\Delta \mathrm{wt}=($ Initial wt - Final wt $) /$ Incubation day Eq.[2]

This was denoted as $\Delta \mathrm{wt}\left(\mathrm{g} \cdot \mathrm{d}^{-1}\right)$. To calculate an approximate $\% \mathrm{~N}$ present in litter between each removal, we averaged $\% \mathrm{~N}$ content of the litter sample (initial and final). The value obtained was denoted as $\mathrm{n}(\% \mathrm{~N})$ :

$\mathrm{n}=(\% \mathrm{~N}$-Initial $+\% \mathrm{~N}$-Final $) / 2 \quad$ Eq. $[3]$

Using Eqs. [2] and [3], the N mineralization rate was calculated as:

$\mathrm{N}$-mineralization $\operatorname{rate}\left(\mathrm{g} \cdot \mathrm{d}^{-1}\right)=\Delta \mathrm{wt} \times \mathrm{n}$

Eq. [4]

The amount of $\mathrm{N}$ released per kilolgram of surface vegetation biomass was calculated in two steps; first the grams of $\mathrm{N}$ remaining in litter bags after each removal were calculated by multiplying dry weight of litter and $\% \mathrm{~N}$ content at each removal date.

Grams of $\mathrm{N}$ remaining $=$ Final wt $\times \% \mathrm{~N}$

Grams of $\mathrm{N}$ released per bag over time were calculated by subtracting the grams of $\mathrm{N}$ remaining after each removal day from the initial $\mathrm{N}$ content of the samples.

$\mathrm{N}$ released $(\mathrm{g})$ per bag $=$ Initial $\mathrm{g} \mathrm{N}-\mathrm{g} \mathrm{N}$ at removal dates

Eq.[6]

Grams of $\mathrm{N}$ released per mesh bag over time were converted to grams of $\mathrm{N}$ released per kilogram of surface vegetation biomass using a conversion factor $x / a$ (where $x$ is the grams of $\mathrm{N}$ released per sample, $a$ is the dry weight of the initial sample), and the resultant value was multiplied by $1000 \mathrm{~g}$ to convert it to $\mathrm{g} \cdot \mathrm{kg}^{-1}$ :

$\mathrm{N}$ released per surface vegetation

$$
\left(g \cdot \mathrm{kg}^{-1}\right)=x / a(1000)
$$

A regression model was fitted for each GMS treatment to predict the release of $\mathrm{N}$ over time from groundcover vegetation. Time (in days) and $\mathrm{N}$ released per unit of surface vegetation $\left(\mathrm{g} \cdot \mathrm{kg}^{-1}\right)$ were the two parameters of this model.

Groundcover biomass estimation. To estimate surface groundcover biomass $\left(\mathrm{kg} \cdot \mathrm{ha}^{-1}\right)$ production under different GMSs, tree-row surface vegetation samples were collected in June 2005 and May and Aug. 2007 from the 2-m wide strips of each GMS treatment using $1-\mathrm{m}^{2}$ quadrangle frames thrown within the tree rows at random sites to collect a representative sample. The groundcover biomass samples were taken to the laboratory and oven-dried at $70{ }^{\circ} \mathrm{C}$ to constant weight. Dry weights were recorded and converted into $\mathrm{kg} \cdot \mathrm{ha}^{-1}$ using a conversion factor $x / a$ [where $x$ is biomass dry weight recorded from samples for each plot, $a$ is litter sample collection area of that plot $\left.\left(1.0 \mathrm{~m}^{2}\right)\right]$, and the resultant value was multiplied by $10,000 \mathrm{~m}^{2}$ to convert it to kilograms biomass production/ha:

Biomass production $\left(\mathrm{kg} \cdot \mathrm{ha}^{-1}\right)=x / a(10000)$ Eq. [8]

Using the regression equations obtained for $\mathrm{N}$ release over time in the mesh litter bag experiment, we estimated the total $\mathrm{N}$ released from groundcover biomass in each GMS during each growing season.

Data logging soil moisture and temperature. Soil temperature and moisture monitoring probes were installed in each plot for continuous data logging. Soil temperatures at 5 - and $25-\mathrm{cm}$ depth in soil were recorded using Campbell Scientific Water/Soil Temperature probes $(\mathrm{P} / \mathrm{N} 107-\mathrm{L})$ rated for -35 to $+50{ }^{\circ} \mathrm{C}$. From 1994 to 2007 , soil volumetric moisture content was recorded using CS-615 Time Domain Reflectometry (TDR) probes (Campbell Scientific, Logan, UT). During the Summer of 2007, the original soil moisture probes were replaced with ECHO20 TDR units (Decagon Devices, WA) placed in the same location as the previous TDR probes. A multiplexer (CSI P/N AM 416) was used to distribute data from the 12 soil moisture probes and 24 soil temperature sensors to a Campbell data logger (CR10X) enabling us to record data at hourly intervals continuously year-round from all sensor probes in the 12 GMS plots (Brown, 2005).

Volumetric soil water content data were averaged weekly for each plot to facilitate interpretation and comparison of these two yearly data sets for practical purposes. When soilmonitoring data were missing as a result of technical problems (e.g., lightning strikes at the site during one summer), we estimated missing values by extrapolating from averages of comparable time intervals for other plots at the site.

Soil nitrogen mineralization. Soil N mineralization rates under different GMS treatments were estimated on the basis of potentially mineralizable nitrogen (PMN) corrected for soil temperature and moisture as suggested by Hadas et al. (1989). The PMN values were obtained from a laboratory incubation experiment with soil samples from the 12 plots 
(Leinfelder, 2010). The $\mathrm{N}$ mineralization (Nt) was estimated on a weekly basis using the first-order rate equation suggested by Stanford and Smith (1972):

$$
\mathrm{Nt}=\mathrm{N}_{0}\left(1-e^{-\mathrm{kt}}\right)
$$

where $\mathrm{N}_{0}$ is the potentially mineralizable $\mathrm{N}$ pool and $\mathrm{k}$ is the rate constant. According to Stanford and Smith (1972), the relationship between soil $\mathrm{N}$ mineralization and soil temperature is explained by the following equation:

$$
\mathrm{k}=10^{[7.71-2758 /(273+\mathrm{T})]}
$$

where $\mathrm{k}$ is the exponential rate constant in $\mathrm{Eq}$. [9] in weekly units. Weekly mean temperatures were obtained from the average recorded soil temperatures at $5-$ and $25-\mathrm{cm}$ depth. Temperatures below $25 \mathrm{~cm}$ were assumed to be similar to those at the 5- to $25-\mathrm{cm}$ depth.

According to Stanford and Epstein (1974), $\mathrm{Nt}$ can be corrected for variable soil moisture conditions in the field by the following equation:

$$
\mathrm{N}_{\mathrm{w} / \mathrm{c}}=\mathrm{Nt} \times \mathrm{WC} / \mathrm{WC}_{\mathrm{opt}}
$$

where $\mathrm{N}_{\mathrm{w} / \mathrm{c}}$ is the amount of $\mathrm{N}$ mineralized under field soil-moisture content (WC) and $\mathrm{WC}_{\mathrm{opt}}$ is the moisture content at field capacity. Based on our previous observations of soil water content at this site, we assigned a value of $0.4 \mathrm{~g} \cdot \mathrm{g}^{-1}$ to $\mathrm{WC}_{\mathrm{opt}}$ (Oliveira and Merwin, 2001) and assumed it was relatively constant over the rooting depth interval of apple trees.

Water analysis for nutrient concentrations. After precipitation or irrigation events, water samples were collected in HDPE Nalgene bottles from access stations in subsurface drainage and surface runoff sampling stations. Samples were filtered through Whatman Glass Microfibre Filter paper (Fisher Scientific, NH) and frozen at $-20^{\circ} \mathrm{C}$ for subsequent analyses of $\mathrm{N}$ and $\mathrm{P}$ concentrations to be run by continuous-flow colorimetry (Perstorp Analytical, Alpkem, OR). Nitrate-N was run on an automated cadmium reduction method to measure nitrate plus nitrite-N. Tests of sample subsets showed that nitrite-N was negligible, and for the purpose of this report, we assumed that nitrate- $\mathrm{N}\left(\mathrm{NO}_{3}-\mathrm{N}\right)$ was the predominant $\mathrm{N}$ form present in our water samples. Orthophosphate $\left(\mathrm{PO}_{4}-\mathrm{P}\right)$ was run on automated ascorbic acid method (Clesceri et al., 1998).

Soil analysis. In Oct. 2005, soil samples were collected with a trowel from $30-\mathrm{cm}$ deep holes beneath the tree canopy of four nested replicate rows within each plot. In Aug. 2007, 12 samples per plot were collected with a 2 -cm-diameter metal core at 0 - to $20-\mathrm{cm}$ depth. Samples were analyzed for nutrient content by Dumas combustion (for $\mathrm{C}$ and $\mathrm{N}$ ), inductively coupled argon plasma spectroscopy (for other macro- and micronutrients), and $\mathrm{pH}$ and organic matter (by loss on ignition) at the CNAL facility.

Nitrogen budget. A balance sheet of nutrient inputs and outputs for each GMS treatment was prepared following a general conceptual model reported by other researchers (Di and Cameron, 2000; Goh and Haynes, 1983; Haynes and Goh, 1980a; Nguyen et al.,
1995; Watson and Atkinson, 1999). Fertilizer applications and $\mathrm{N}$ inputs from irrigation, precipitation, and mulch were tabulated as external $\mathrm{N}$ inputs to the orchard. The $\mathrm{N}$ releases from aboveground biomass decomposition, litter fall and pruned wood, and soil mineralization were tabulated as internal fluxes; and $\mathrm{N}$ losses through harvested fruits, surface runoff, and subsurface leaching were tabulated as outputs from the orchard. Biological $\mathrm{N}$ fixation, atmospheric particulate $\mathrm{N}$ deposition, $\mathrm{N}$ immobilization in soil, denitrification or ammonia volatization from soil, and $\mathrm{N}$ diffusion from tree canopies were not assessed in our study.

During 2005, water flow data were recorded from May to December, and samples to estimate $\mathrm{NO}_{3}-\mathrm{N}$ and $\mathrm{PO}_{4}-\mathrm{P}$ concentrations in water flow were taken from June to November. Data from a decade of previous observations at this site for $\mathrm{N}$ concentrations and flow volumes were used to estimate nutrient losses during Jan., Feb., Mar., Apr., May, and Dec. 2005. A subset of surface runoff and subsurface leaching samples was analyzed for total $\mathrm{N}$ content in all forms, and a correction factor was calculated to estimate total $\mathrm{N}$ losses through surface and subsurface water in the final $\mathrm{N}$ budget.

The $\mathrm{N}$ loss in harvested fruits from the orchard in 2005 was estimated using an average fruit yield per GMS from 2000 to 2005, because in 2005-as a result of unusually hot weather during June after chemical thinning sprays - fruit yields were abnormally low in all the treatments. To estimate the $\mathrm{N}$ mineralization from mulch biomass, we assumed that each bark mulch application would take 5 years to decompose and release its total $\mathrm{N}$ content and calculated its yearly $\mathrm{N}$ input as $20 \%$ of its total N content. Mulch was applied in 1992, 1995, 1998, 2000, 2002, and 2005 at a rate of $27 \mathrm{~kg}$ of dry mulch $/ \mathrm{m}^{2}$ with an average dry weight $\mathrm{N}$ content of $0.47 \%$. All calculations for constructing $\mathrm{N}$ budgets reflected the fact that the GMS treatments covered one-third of a hectare (only tree rows), whereas the other two-thirds of the site was covered with the same turfgrass drive lanes in all treatments.

Precipitation and irrigation water. Precipitation was recorded throughout the study at an automated weather station nearby in the same orchard. During the Summer of 2005, trees were irrigated once in May after the ground fertilizer applications and several times during June and July. During the Summer of 2007, trees were irrigated only twice, during June. The $\mathrm{N}$ and $\mathrm{P}$ concentrations in irrigation water were obtained for 2005 and 2007 from regional monitoring reports for Cayuga Lake (the source of irrigation water at this site); for precipitation $\mathrm{N}$ and $\mathrm{P}$ content, data were obtained from the National Atmospheric Deposition Project monitoring location NY67 in nearby Ithaca, NY.

Data analysis. Soil and fruit nutrient analyses, tree growth and yield, and total leaf and groundcover biomass were analyzed as a one-way analysis of variance model (JMP, Version 7; SAS Institute Inc., Cary, NC). A repeated-measures model was used to analyze water flow and nutrient losses within years, and only data recorded for the same period of time in both years were compared for statistical analyses. The $\mathrm{N}$ budget table was elaborated with the entire set of data recorded in both years.

\section{Results}

Total groundcover biomass was greatest in Sod plots during 2005 and 2007; Sod had almost twice the groundcover biomass in other treatments during 2005 and three times more biomass than other treatments in 2007 (Table 1). There was sparse groundcover biomass in the two herbicide and the bark mulch plots during the early May sampling times each year as a result of dormant season growth of groundcover vegetation in these three GMSs.

No differences in number or dry weight biomass of leaves or pruned wood per tree were observed among the GMS treatments (data not presented).

Trends in soil water content during 2005 and 2007 were complex and varied between the 2 years as well as among treatments during each growing season (Fig. 1). Soil water content under Sod was greater than other treatments in the first part of 2005. The PreHerb plots were drier than the other GMSs during most of 2005, which was an unusually warm and dry growing season from May to September. During 2007, the Sod plots had greater soil moisture during the spring and summer months in comparison with other GMS plots. The PreHerb plots had the lowest soil water content values for most of the 2007 growing season.

The estimated rate of $\mathrm{N}$ release from groundcover residues in litter decomposition simulations was highest for the Mulch treatment in both years (Fig. 2) and higher in all GMSs during 2005 compared with 2007. On a per-gram-biomass basis, there were no significant differences among the GMSs for $\mathrm{N}$ release from groundcover residues in 2005; but in 2007, the Mulch plot ground cover litter released more $\mathrm{N}$ than the other treatments. When litter $\mathrm{N}$ release was regressed on the initial C-to-N ratios of groundcover residues in each GMS during 2005, there was a significant negative trend for $\mathrm{N}$ release as the $\mathrm{C}-$ to- $\mathrm{N}$ ratio of groundcover residues increased (Fig. 3 ). In contrast, during 2007 when $\mathrm{N}$ fertilizer

Table 1. Total groundcover biomass production $\left(\mathrm{kg} \cdot \mathrm{ha}^{-1}\right)$ under four groundcover management system (GMS) treatments. ${ }^{\mathrm{Z}}$

\begin{tabular}{lrr}
\hline GMS treatments & Yr 2005 & Yr 2007 \\
\hline PreHerb & $855.7 \mathrm{~b}^{\mathrm{y}}$ & $526.7 \mathrm{~b}$ \\
PostHerb & $1035.7 \mathrm{~b}$ & $793.4 \mathrm{~b}$ \\
Sod & $1754.0 \mathrm{a}$ & $2100.2 \mathrm{a}$ \\
Mulch & $966.3 \mathrm{~b}$ & $653.3 \mathrm{~b}$ \\
\hline z & \multicolumn{1}{c}{ balues presented are means of three replites per }
\end{tabular}

${ }^{\mathrm{z}}$ Values presented are means of three replicates per GMS.

yDifferent letters within columns denote significant differences in means among GMS treatments. Letters were generated from Tukey's honestly significant difference test at $P \leq 0.05$. 

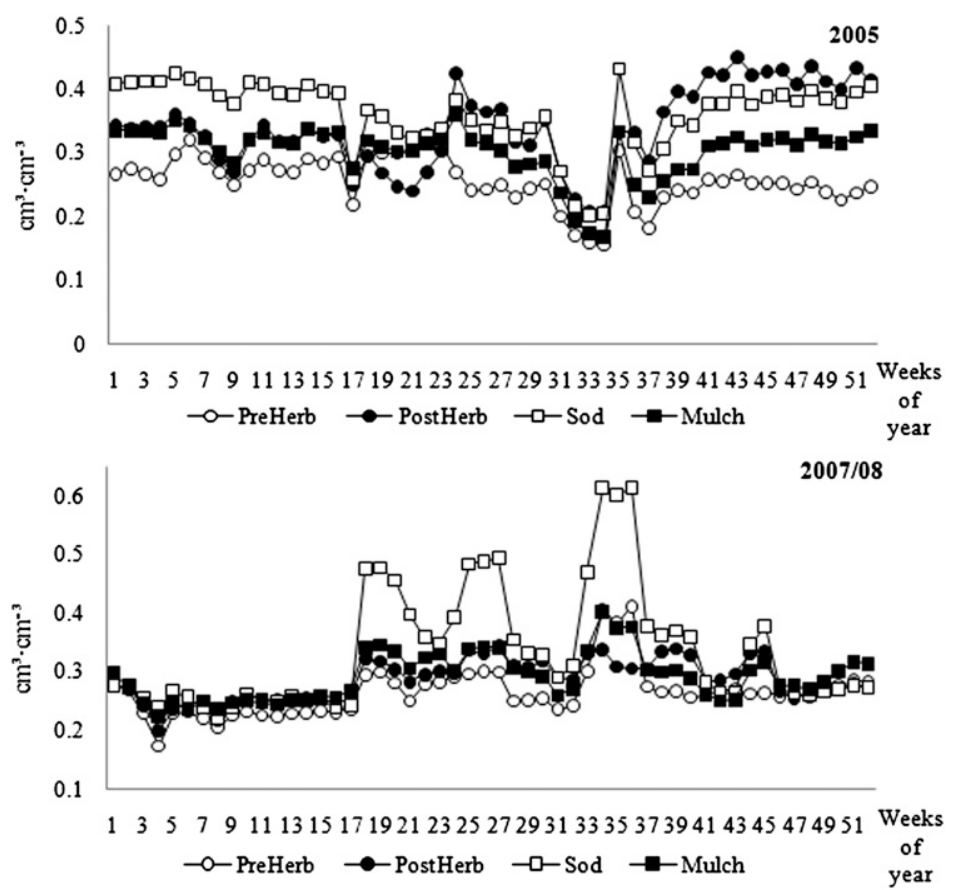

Fig. 1. Soil water moisture $\left(\mathrm{cm}^{3} \cdot \mathrm{cm}^{-3}\right)$ content under different groundcover management system treatments. Daily measurements were taken for 51 weeks in 2005 and for Weeks 18 to 51 in 2007 plus Weeks 1 to 17 during 2008 to extrapolate for missing data.
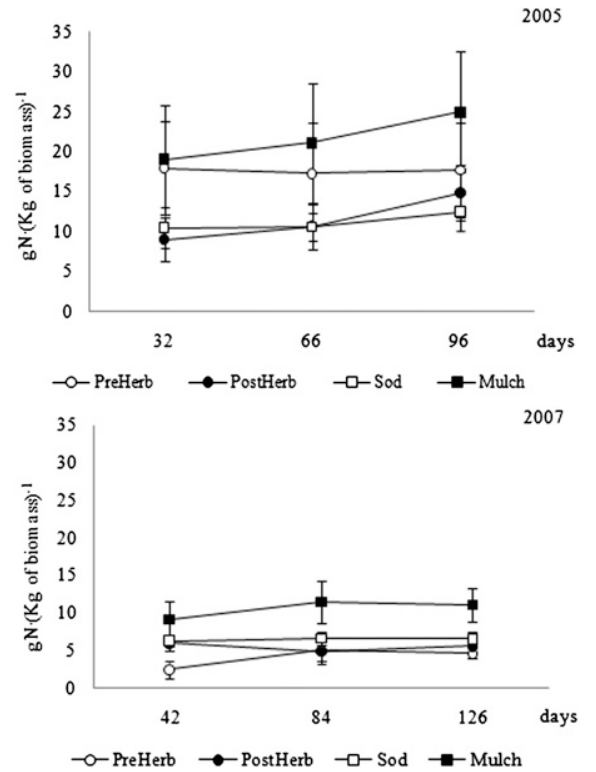

Fig. 2. Grams of nitrogen released per kilogram of biomass over time in four groundcover management system treatments during summer of 2005 and 2007. Values were based on $96 \mathrm{~d}$ in 2005 and $126 \mathrm{~d}$ in $2007(\mathrm{n}=3$, mean $\pm \mathrm{SE})$.

was not applied beneath the trees, the C-to-N ratios for groundcover biomass were higher, and the amount of $\mathrm{N}$ released from litter decomposition was lower than in 2005.

Soil total carbon, nitrogen, and carbon-tonitrogen ratios. Data are presented elsewhere (Atucha et al., 2011). Soil mineralization rates under different GMSs, estimated as PMN and corrected for soil temperature and moisture, differed greatly among the four treatments.
The PMN/ha of soil to 0.5-m depth followed similar trends in both years (Fig. 4). The treatment rankings for $\mathrm{PMN}$ rates were Mulch $>$ Sod $>$ PostHerb $>$ PreHerb; and the $\mathrm{N}$ mineralization rate of PreHerb soil was only $10 \%$ that of Mulch soil.

The $\mathrm{N}$ inputs from precipitation and irrigation were generally very low at this site, providing $\approx 1 \mathrm{~kg} \mathrm{~N} / \mathrm{ha}$ cumulatively each year (Fig. 5). The highest $\mathrm{N}$ input from precipitation and irrigation water was during midsummer each year, but it did not surpass $0.2 \mathrm{~kg} \mathrm{~N} /$ ha during any single month in either year.

The outflows from leaching and runoff varied substantially between the 2 years, from month to month within years, and among the GMSs (Table 2). In general, water outflows from subsurface leaching were greater than those from surface runoff during 2005. During that year there was more surface runoff in PostHerb than in Mulch and PreHerb plots, but runoff was equivalent in Sod versus the other three treatments (Table 2). The time effect for surface runoff was significant with the lowest runoff volumes observed during May and Dec. 2005 - the months with the lowest precipitation that year (Fig. 5). During 2007, the surface water runoff volumes were higher than those in 2005 for the PreHerb, PostHerb and Sod treatments (Table 2). Like in the previous year, Mulch plots had the lowest surface runoff volumes and differed significantly from PostHerb plots, which had the greatest volumes of runoff during both 2005 and 2007.

The water efflux volumes through subsurface leaching during 2005 did not differ significantly among GMS treatments (Table 2). During 2007, there were treatment differences in leaching outflows; they were significantly greater in Mulch than in PreHerb plots but similar among the other treatments. Water outflows through subsurface drainage differed substantially over time in both years, and outflow was correlated with precipitation and soil freezing/thawing events each winter. The greatest leachate outflows were observed during Oct. and Nov. 2005 and in Nov. and Dec. 2007. The lowest amounts of subsurface outflow occurred during May in both years (Table 2).

There were substantial differences for $\mathrm{NO}_{3}-\mathrm{N}$ concentrations in runoff water among the four GMSs during 2005 but not 2007 (Table 3). For the Mulch and Sod plots, $\mathrm{NO}_{3}$ $\mathrm{N}$ runoff concentrations were lower in 2005 than in 2007, and during 2005, the $\mathrm{NO}_{3}-\mathrm{N}$ concentrations in runoff were greater in herbicide plots than in Sod and Mulch plots. However, during 2007, when $\mathrm{N}$ fertilizer was not applied, no differences were observed in $\mathrm{NO}_{3}-\mathrm{N}$ runoff concentrations among the GMSs. During 2005, the lowest $\mathrm{NO}_{3}-\mathrm{N}$ runoff concentrations were observed in Oct. and Nov., and the highest concentration was recorded in June. During 2007, the N concentrations in runoff water were significantly lower in August and higher during June, July, and October.

Leachate water $\mathrm{NO}_{3}-\mathrm{N}$ concentrations were also much higher during 2005 than 2007 (Table 3). PreHerb plots had the smallest observed leachate $\mathrm{NO}_{3}-\mathrm{N}$ concentrations both years, although they were not significantly different from those in other GMSs. During 2007, $\mathrm{NO}_{3}-\mathrm{N}$ concentrations in leachate water averaged $90 \%$ lower than those observed in 2005. Mulch plots had the highest concentration of $\mathrm{NO}_{3}-\mathrm{N}$ in subsurface leachate (Table 3 ). The time effect was significant for $\mathrm{NO}_{3}-\mathrm{N}$ concentrations in subsurface leachate water during both years, but the trends were complex and appeared to be weather-driven. During both 2005 and 2007, November was the month with the lowest concentrations of $\mathrm{NO}_{3}-\mathrm{N}$ in leachate (Table 3).

The $\mathrm{PO}_{4}-\mathrm{P}$ concentrations in surface runoff and subsurface leachate water were generally very low (ranging from 0.03 to 1.1 $\mathrm{mg} \cdot \mathrm{L}^{-1}$ in leachate and from 0.1 to $1.3 \mathrm{mg} \cdot \mathrm{L}^{-1}$ in runoff) and did not differ consistently among GMSs during either year of this study (data not presented).

Overall, the total calculated $\mathrm{N}$ losses $(\mathrm{kg}$ $\mathrm{N} / \mathrm{ha}$ ) in runoff from this orchard during 2005 were greater in the PreHerb and PostHerb than in the Sod and Mulch treatments (Fig. 6A). During 2007, N runoff losses were again higher in the PostHerb treatment compared with other GMSs (Fig. 6C). For calculated N losses (kg N/ha) from subsurface leaching, Mulch plots generally had the greatest N leaching efflux during both years of observations despite substantial variation from month to month each year (Figs. 6B and 6D).

Soil nutrient availability. Results are presented elsewhere (Atucha et al., 2011, in press).

Nitrogen budgets. We compiled annual $\mathrm{N}$ budgets for each GMS during 2005 when $\mathrm{N}$ fertilizer was applied and for 2007 when no N fertilizer was applied, normalizing calculations 

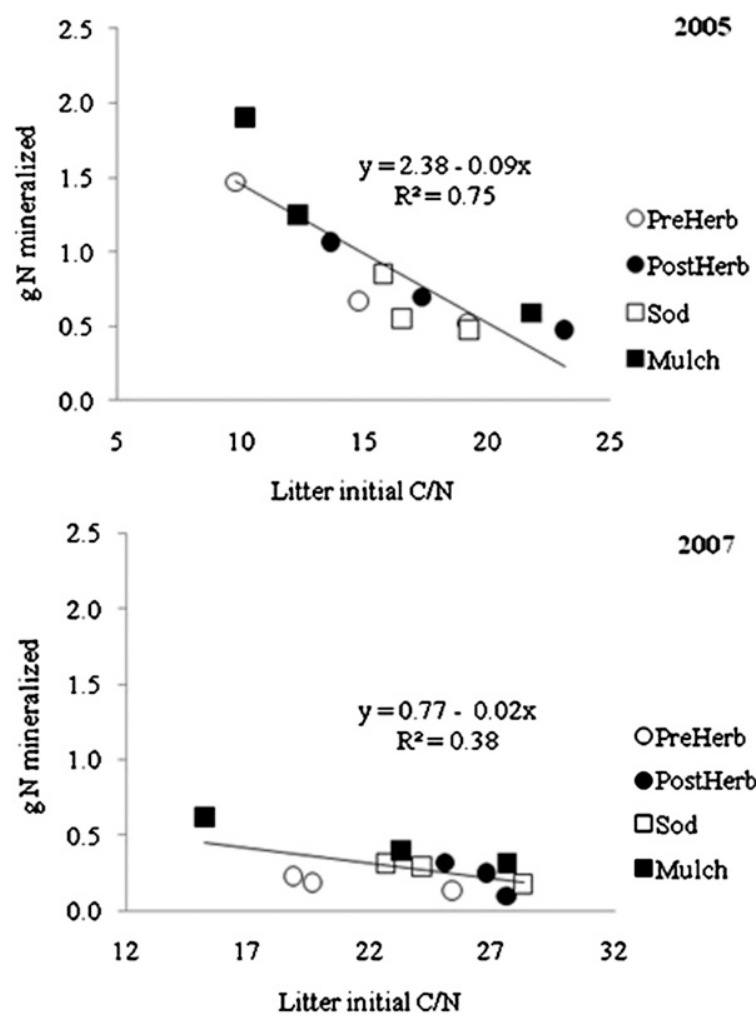

Fig. 3. Grams of nitrogen $(\mathrm{N})$ released in relation to the initial $\mathrm{C}$-to-N ratio of litter residue during the summer of 2005 and $2007 ; P$ value for model fit $=0.0002$ and 0.0331 , respectively. $\mathrm{C}=$ carbon.

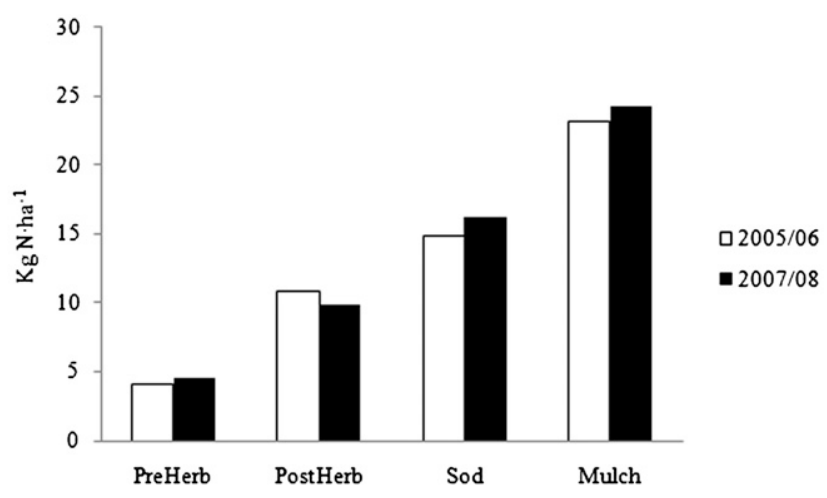

Fig. 4. Calculated estimates of soil nitrogen $(\mathrm{N})$ mineralization $(\mathrm{kg} \mathrm{N} / \mathrm{ha})$ under four groundcover management system treatments in 2005 and 2007.

for an area of 1 ha (Table 4). The $\mathrm{N}$ mineralization inputs from Mulch were twofold greater in 2005 than in 2007 as a result of the recent mulch application and cumulative decomposition from previous applications in 2005. The exogenous inputs (fertilizers, irrigation, and precipitation) were equivalent for all GMS treatments except Mulch, and there were substantial differences between 2005 and 2007, presumably as a result of the $\mathrm{N}$ fertilizer applications in 2005. External $\mathrm{N}$ inputs from the Mulch were estimated as three and 69 times greater than those in other GMSs during 2005 and 2007, respectively, reflecting the $\mathrm{N}$ inputs from mulch biomass input and decomposition.

Nutrient recycling through groundcover biomass decomposition, soil mineralization, litter fall, and pruned wood constituted in- ternal fluxes that differed among the GMSs annually and between the 2 years. The combined soil $\mathrm{N}$ mineralization and recycling surface biomass accounted for $\approx 60 \%$ of aggregate internal $\mathrm{N}$ fluxes in all treatments during both years. Total internal fluxes were lower in the two herbicide GMSs than in Mulch and Sod treatments during both years. For 2005 and 2007, harvested fruit represented more than $70 \%$ of $\mathrm{N}$ outputs from this orchard. Nitrogen losses through surface runoff were $\approx 1 \%$ to $4 \%$ of $\mathrm{N}$ losses, and subsurface leaching represented $18 \%$ to $22 \%$ of $\mathrm{N}$ losses during 2005. In contrast, during the 2007-2008 observations, surface runoff $\mathrm{N}$ losses were two times greater than subsurface leaching $\mathrm{N}$ losses, except for Mulch plots. The overall balance for $\mathrm{N}$ among GMS treatments in 2005 was positive (inputs exceeded outputs), and it was greater in the Mulch and Sod than in other GMSs. In 2007, the overall balance for $\mathrm{N}$ in this orchard was negative for PreHerb and PostHerb and positive for the Mulch and Sod treatments.

\section{Discussion}

Previous studies have shown that litter decomposition rate and $\mathrm{N}$ mineralization are influenced by plant residue $\mathrm{C}$-to- $\mathrm{N}$ ratios (Chapman et al., 1988; Hansen and Coleman, 1998; Paustian et al., 1997; Wardle et al., 2001), and this was also evident in our study. Long-term SOM mineralization studies indicate that amendments with low C-to-N ratios increase net mineralization (Hadas et al., 1996; Trinsoutrot et al., 2000; Whitmore and Groot, 1997). We observed that more $\mathrm{N}$ was released from groundcover residues in the Mulch GMS in comparison with other treatments (Fig. 2), which could be the result of the lower C-to-N ratio of Mulch vegetation litter. The greater $\mathrm{N}$ release from litter decomposition in 2005 versus 2007 for all GMSs (Fig. 2) could also be attributed to lower C-to-N ratios in 2005 groundcover residues because of the $\mathrm{N}$ fertilization that year.

Although groundcover vegetation characteristics reportedly influence litter decomposition and mineralization rates, Goh and Tutua (2004) did not find correlation between litter quality and $\mathrm{N}$ release in their experiment. This was also observed in our study, in which groundcover litter from PreHerb plots had the lowest C-to-N ratio in 2007 but nonetheless released the least $\mathrm{N}$ among all treatments that year (Fig. 3). Some reports have suggested that herbicide residues may alter soil microbial communities (Tu, 1996; Yao et al., 2005), and such changes in soil microbial diversity or functionality could affect plant litter decomposition rates (Sall et al., 2006).

Abiotic factors such as soil moisture conditions may influence litter decomposition more than biotic factors when significant differences in soil moisture content are observed under different soil management systems (Wardle et al., 2001, 1993). Wetting-drying cycles in soil reportedly suppress microbial populations (Shields et al., 1974; Van Veen et al., 1987) and GMSs that buffer these effects could increase soil microbial activity over time (Wardle et al., 1993; Yao et al., 2005).

During 2005 and 2007, the Mulch treatment usually had the lowest volumes of surface runoff and the greatest amounts of subsurface leaching (Table 2). These observations reflect biomass mulches' widely reported capacities to restrain surface water flows and to absorb and infiltrate greater amounts of precipitation compared with the bare soils typical of herbicide or cultivation GMSs (Hogue and Neilsen, 1987). A previous study of soil conditions at our site by Oliveira and Merwin (2001) showed lower bulk density, greater porosity, and higher infiltration capacities and saturated hydraulic conductivity in soil under Mulch in comparison with other GMSs; this was consistent with the increased infiltration 


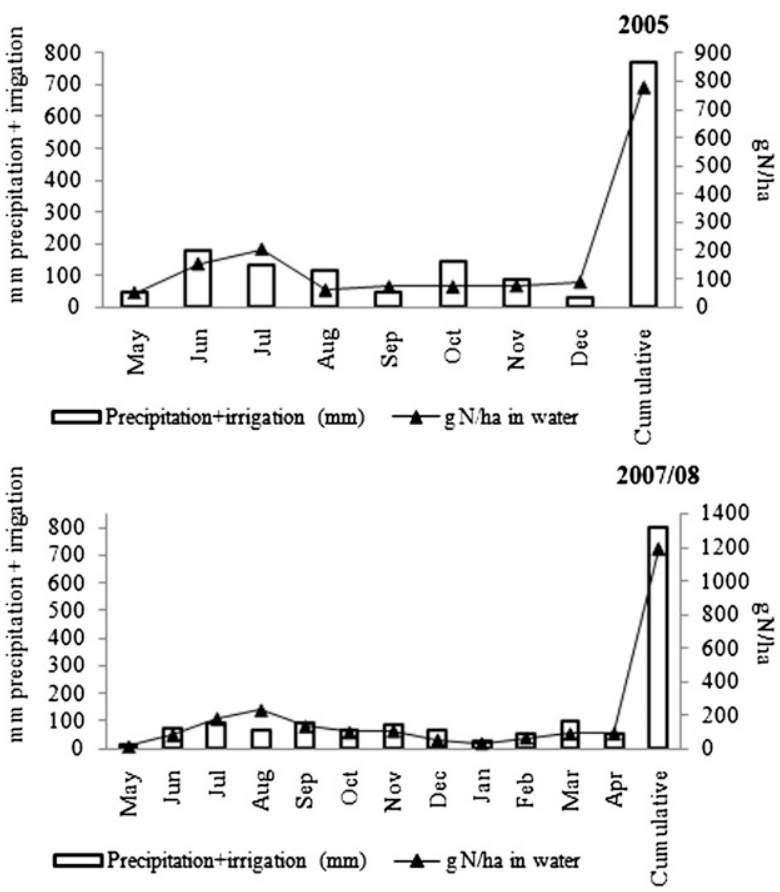

Fig. 5. Monthly precipitation plus irrigation and calculated water nitrogen inputs for 2005 and 2007-2008 based on irrigation water analyses at the orchard and precipitation data from National Oceanic Atmospheric Association weather stations in nearby Ithaca, NY.

Table 2. Water flow $\left(\mathrm{L} \cdot \mathrm{m}^{-2}\right)$ from runoff and subsurface leachate plots collected during May to Dec. 2005 and 2007.

\begin{tabular}{|c|c|c|c|c|}
\hline & \multirow{2}{*}{\multicolumn{2}{|c|}{$\frac{\text { Surface runoff water volumes }}{\left(\mathrm{L} \cdot \mathrm{m}^{-2}\right)}$}} & \multirow{2}{*}{\multicolumn{2}{|c|}{$\frac{\text { Subsurface leaching water volume }}{\left(\mathrm{L} \cdot \mathrm{m}^{-2}\right)}$}} \\
\hline & & & & \\
\hline & \multicolumn{2}{|c|}{ May to Dec. } & \multicolumn{2}{|c|}{ May to Dec. } \\
\hline & 2005 & 2007 & 2005 & 2007 \\
\hline \multicolumn{5}{|l|}{ Treatment } \\
\hline PreHerb & $11.6 \pm 3.8 b^{x}$ & $32.9 \pm 9.7 \mathrm{ab}$ & $34.2 \pm 11.9 \mathrm{NS}$ & $44.7 \pm 18.4 b$ \\
\hline PostHerb & $30.7 \pm 9.9 \mathrm{a}$ & $87.9 \pm 24.8 \mathrm{a}$ & $47.7 \pm 13.7$ & $41.5 \pm 14.6 \mathrm{ab}$ \\
\hline Mulch & $6.7 \pm 1.1 \mathrm{~b}$ & $6.6 \pm 1.0 \mathrm{~b}$ & $53.5 \pm 16.1$ & $61.7 \pm 21.3 \mathrm{a}$ \\
\hline Sod & $21.0 \pm 6.4 \mathrm{ab}$ & $36.6 \pm 11.4 \mathrm{ab}$ & $42.3 \pm 11.5$ & $51.4 \pm 16.2 \mathrm{ab}$ \\
\hline \multicolumn{5}{|l|}{ Month } \\
\hline May & $1.8 \pm 0.4 \mathrm{~b}$ & $3.4 \pm 2.9 \mathrm{e}$ & $1.3 \pm 0.7 \mathrm{~d}$ & $1.1 \pm 1.0 \mathrm{e}$ \\
\hline June & $9.1 \pm 1.4 \mathrm{a}$ & $40.5 \pm 22.8 \mathrm{abc}$ & $6.6 \pm 2.2 \mathrm{c}$ & $17.2 \pm 4.9 \mathrm{c}$ \\
\hline July & $30.9 \pm 16.2 \mathrm{a}$ & $27.6 \pm 14.8 \mathrm{bcd}$ & $40.7 \pm 11.1 \mathrm{bc}$ & $13.5 \pm 4.5 \mathrm{~cd}$ \\
\hline August & $10.0 \pm 1.2 \mathrm{a}$ & $76.9 \pm 28.1 \mathrm{ab}$ & $8.6 \pm 2.4 \mathrm{c}$ & $46.4 \pm 7.8 \mathrm{~b}$ \\
\hline September & $16.6 \pm 5.9 \mathrm{a}$ & $7.6 \pm 1.9 \mathrm{cde}$ & $6.8 \pm 2.0 \mathrm{~cd}$ & $3.4 \pm 0.9 \mathrm{de}$ \\
\hline October & $18.5 \pm 5.9 \mathrm{a}$ & $3.4 \pm 1.6 \mathrm{de}$ & $116.0 \pm 22.5 \mathrm{ab}$ & $3.3 \pm 1.1 \mathrm{de}$ \\
\hline November & $50.4 \pm 14.3 \mathrm{a}$ & $41.5 \pm 13.9 \mathrm{abc}$ & $129.4 \pm 19.8 \mathrm{a}$ & $71.8 \pm 10.8 \mathrm{~b}$ \\
\hline December & $3.2 \pm 1.5 \mathrm{~b}$ & $130.5 \pm 36.0 \mathrm{a}$ & $45.9 \pm 18.8 \mathrm{bc}$ & $241.8 \pm 30.2 \mathrm{a}$ \\
\hline
\end{tabular}

${ }^{\mathrm{z}}$ Water flow was determined as total water flowing out from each groundcover management system treatment by averaging amounts from three replicates and observed mean values and sEs are presented for each corresponding GMS. ${ }^{y}$

${ }^{\mathrm{y}}$ Data were transformed using Log $($ data +1$)$, and transformed means were tested for significance level. Values presented in the table are from untransformed data.

${ }^{x}$ Letters were generated from Tukey's honestly significant difference test at $P \leq 0.05$.

NS Non-significantly different at $P \leq 0.05$.

and subsurface leaching of water observed in Mulch plots during our study.

Surface vegetation can also increase infiltration as a result of macropores and soil channels created by root penetration, which provide preferential flow paths when those roots die and decompose (Merwin et al., 1996). Leachate volumes were equivalent and runoff volumes were lower in the relatively weedfree PreHerb plots than in the PostHerb plots, in which there was sparse groundcover veg- etation late in the growing season and throughout the dormant season each year. However, in 2005, the PostHerb plots had the highest soil moisture content from late September until the end of that year (Fig. 1). Soils with high moisture content have less available pore volume for water storage capacity compared with drier soils and are more likely to be saturated and incapable of absorbing water during extended wetting events (Easton et al., 2007). Higher soil moisture content during the heavy rainstorms in Oct. and Nov. 2005 may have increased runoff rates in the PostHerb plots versus the other GMSs where the soil was less saturated. During 2007, surface runoff volumes were once again higher in PostHerb compared with other GMSs. A random confounding factor in these observations was the overflow of a diversion ditch along the uphill edge of the orchard near one of the PostHerb plots, which led to brief surface flows into the adjacent plots during a few intense rainfalls in both years of this study.

The $\mathrm{N}$ inputs from Mulch were substantially greater than in other GMS treatments (Table 4) as a result of organic matter mineralization from mulch residues that increased $\mathrm{N}$ availability over the years and elevated the potential for $\mathrm{N}$ leaching from Mulch plots. However, the observed $\mathrm{N}$ losses through surface runoff and subsurface leaching from Mulch plots were not proportional to the high $\mathrm{N}$ inputs in this GMS (Fig. 6). Yao et al. (2005) attributed this prolonged retention of $\mathrm{N}$ in Mulch plots - even after 14 years of mulch applications - to the high C-to-N ratio in bark mulch and the increased soil microbial activity in that GMS, which incorporated most of the $\mathrm{N}$ mineralized from mulch residues into microbial biomass and stable forms of SOM.

In the Sod plots, uptake and recycling of soil nutrients through surface vegetation retained and used much of the $\mathrm{N}$ that might otherwise have runoff, decreasing $\mathrm{N}$ losses through surface runoff compared with the PreHerb treatment (Table 3; Fig. 6). Although considerable amounts of $\mathrm{N}$ were mineralized from Sod residues (Figs. 2 and 3), and there was a substantial amount of white clover (Trifolium repens L.) in the Sod plots that presumably released $\mathrm{N}$ during frequent mowing in this treatment, there were minimal runoff losses of N or P from the Sod plots. Similar effects of groundcover vegetation on surface runoff and nutrient loss were reported by Haynes (1980), Hogue and Neilsen (1987), Merwin et al., (1994), and Skroch and Shribbs (1986). Contrary to the trends observed in Sod, Mulch, and PostHerb treatments, during 2005, the PreHerb plots had more $\mathrm{N}$ loss through surface runoff than subsurface leachate (Table 3). Because of negligible groundcover residue inputs over the course of this study in the bare soil of PreHerb plots, the soil pore volume, infiltration capacities, hydraulic conductivity, and aggregate stability all decreased compared with the other GMSs (Haynes, 1980; Oliveira and Merwin, 2001). These conditions apparently exacerbated $\mathrm{N}$ loss from PreHerb plots through surface runoff instead of subsurface leachate after the $\mathrm{N}$ fertilizer application in 2005.

Considering water quality, the average $\mathrm{NO}_{3}-\mathrm{N}$ concentrations in surface runoff water during both years of this study ranged from 0.67 to $5.83 \mathrm{mg} \cdot \mathrm{L}^{-1}$ for all GMSs (Table 3 ). These values are below the US-EPA-recommended water quality standards for human health, set at $10 \mathrm{mg} \cdot \mathrm{L}^{-1}$ for $\mathrm{NO}_{3}-\mathrm{N}$ (US-EPA, 2006). However, during 2005, the $\mathrm{NO}_{3}-\mathrm{N}$ concentrations in leachate water from Mulch 
Table 3. Average nitrate- $\mathrm{N}\left(\mathrm{NO}_{3}-\mathrm{N}\right)$ concentration $\left(\mathrm{mg} \cdot \mathrm{L}^{-1}\right)$ in runoff and leachate samples collected from June to Nov. 2005 and 2007.

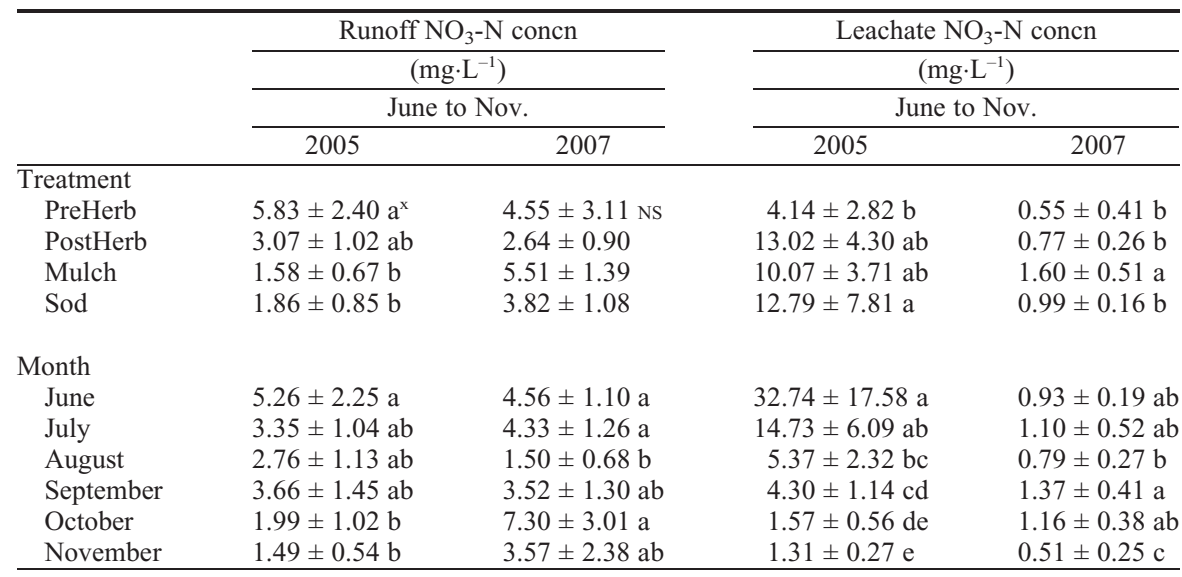

${ }^{2}$ Values correspond to means \pm SES from three replicates for each groundcover management system. ${ }^{y}$

${ }^{y}$ Data were transformed using log transformation. Transformed means were tested for significance level.

Values presented in the table are from untransformed data.

${ }^{x}$ Letters were generated from Tukey's honestly significant difference test at $P \leq 0.05$.

Ns Non-significantly different at $P \leq 0.05$.
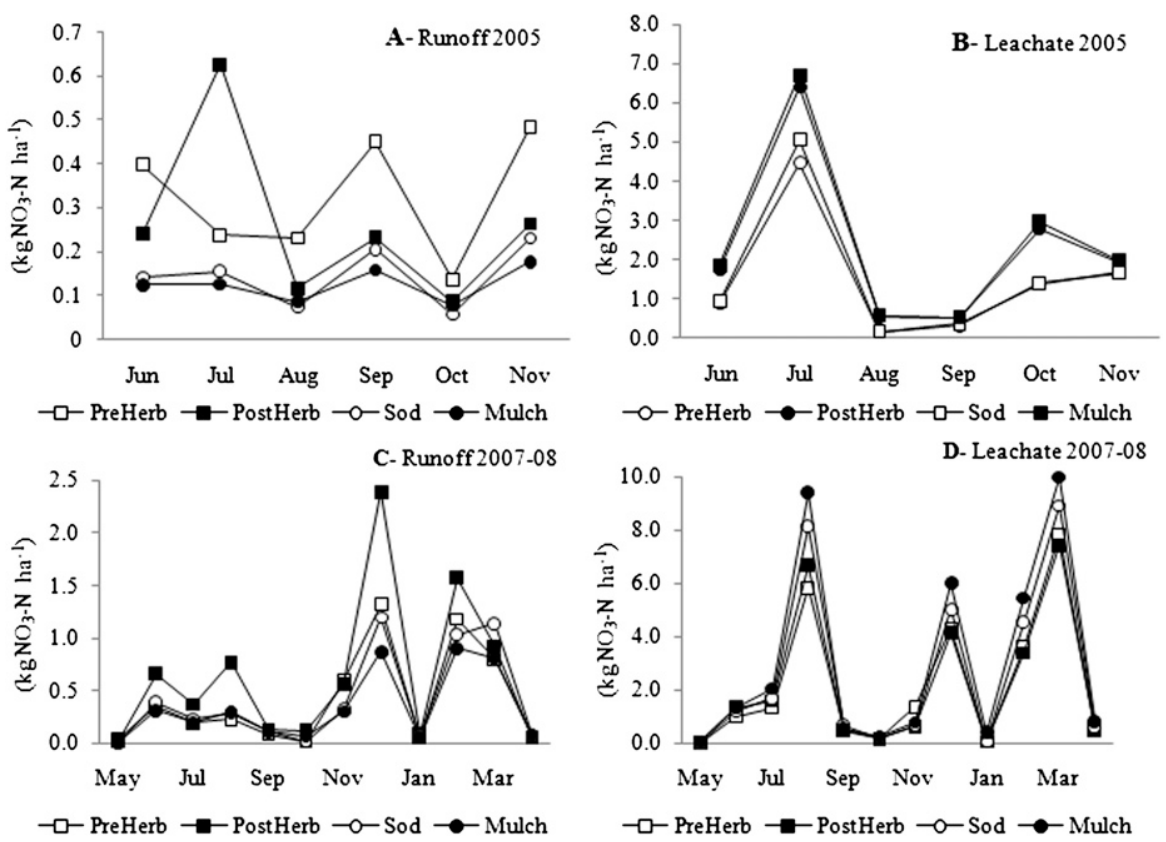

Fig. 6. (A-D) Estimated nitrogen $(\mathrm{N}) \operatorname{losses}\left(\mathrm{kg} \mathrm{NO}_{3}-\mathrm{N} / \mathrm{ha}\right)$ in runoff and leachate from June to Nov. 2005, May to Dec. 2007, and Jan. to Apr. 2008. SEMs for PreHerb, PostHerb, Sod, and Mulch treatments in A were $0.2,0.2,0.04$, and 0.02 , respectively; in $\mathbf{B}$, the sems were $0.4,0.5,0.8$, and 0.8 , respectively; in $\mathbf{C}$, the SEMS were $0.2,0.3,0.2$, and 0.04 , respectively; and in $\mathbf{D}$, the sEMs were $0.3,0.3,0.2$, and 0.9 , respectively. The $\mathrm{N}$ loss was calculated as total outflow $\mathrm{N}$ in each treatment $(\mathrm{n}=3)$ considering that groundcover management system treatment areas (tree rows) comprised one-third of the orchard floor, and the other two-thirds consisted of sod drive lanes throughout the site.

and Sod plots occasionally exceeded this potable groundwater standard. The $\mathrm{PO}_{4}-\mathrm{P}$ runoff and leachate concentration values we observed in this orchard were below the US-EPA reference condition values ( 20.63 to $80 \mathrm{mg} \mathrm{P} / \mathrm{L}$ ) observed in streams of upstate New York (US-EPA, 2000). Compared with $\mathrm{NO}_{3}-\mathrm{N}$, in which the concentrations in leachate samples spiked during June and July 2005 after N fertilization, there was a much smaller peak for $\mathrm{PO}_{4}-\mathrm{P}$ concentrations in leachate and runoff samples in June 2005 after P fertilizer applications. These observations probably reflect the high P-sorption capacity of the silty clay soil in this orchard, relative to the amount of $\mathrm{P}$ fertilizer in that single application during 2005 (Sims et al., 1998).

Nutrient loss trends above- and belowground were correlated temporally in both years of this study (Fig. 6), suggesting that $\mathrm{N}$ losses could be driven primarily by precipitation events rather than soil conditions associated with different GMS treatments. For example, in Nov. and Dec. 2007, the high losses of $\mathrm{N}$ in runoff and leaching water (Fig. 6) were coupled with rainstorm events during those months (Fig. 5). Similarly, a thaw during Mar. 2008 led to high $\mathrm{N}$ losses in both runoff and leaching from all GMSs.

The $\mathrm{N}$ budgets for two different growing seasons and fertilizer regimes in the 13th (2005) and 15th (2007) years of this study integrate and illustrate the underlying trends among these four GMSs. Admittedly, these $\mathrm{N}$ budgets do not include all possible inputs and outputs in this orchard but they represent the first published estimates for $\mathrm{N}$ cycles and allocations under different orchard GMSs based on extensive long-term monitoring of nutrient dynamics in a representative commercial orchard. We did not have the facilities to measure particulate $\mathrm{N}$ deposition, gaseous $\mathrm{N}$ losses, or biological $\mathrm{N}$ fixation (which was probably substantial given the prevalence of white clover in the drive lanes and Sod plots of this orchard). However, these $\mathrm{N}$ budget estimates will be useful for improving the optimization of fertilizer programs in comparable orchards.

Collectively, our observations suggest that labile $\mathrm{N}$ in orchards is lost primarily through subsurface leaching rather than surface runoff regardless of specific GMS effects. The N leaching losses in our study were proportionally lower than those reported by Haynes and Goh (1980a) for a fertilized apple orchard, where the observed $\mathrm{N}$ losses were approximately equally distributed between fruit crop removal and leaching, but this discrepancy may be the result of lower yields in their study compared with ours. Ventura et al. (2005) reported that $8 \%$ of fertilizer $\mathrm{N}$ input was lost through leaching outflows in a 2-year-old pear (Pyrus communis L.) orchard. However, in our study, the $\mathrm{N}$ losses through leaching accounted for $30 \%$ of mineral $\mathrm{N}$ fertilizer inputs; we attribute these differences to lower $\mathrm{N}$ demand from the mature apple trees in our study versus the newly planted pear trees in the previous report. The internal $\mathrm{N}$ recycling in our orchard was lower than that reported by Haynes and Goh (1980a), who estimated that $93 \%$ of $\mathrm{N}$ returns came from recycling surface vegetation and $6 \%$ from leaf litter fall in the warmer climate of New Zealand where surface vegetation grows year-round compared with $38 \%$ and $22 \%$, respectively, that we observed in the colder NY climate with a shorter growing season. Our estimates of $\mathrm{N}$ recycling from tree prunings pulverized in situ with a flail mower were similar to those reported by Greenham (1980) for a mature apple orchard in the United Kingdom.

The generally positive balance for $\mathrm{N}$ supply in our study suggests that trees in Sod and Mulch plots were not N-limited, but the reasons underlying that positive $\mathrm{N}$ balance differed between Sod and Mulch treatments. For Sod trees, the positive $\mathrm{N}$ balance was driven by lower yields and greater $\mathrm{N}$ cycling from groundcover residues and soil mineralization; in Mulch trees, the $\mathrm{N}$ surplus was driven primarily by mulch residue humification and SOM N mineralization. Considering the cumulative increase in SOM and $\mathrm{N}$ mineralization in Mulch plots over 15 years, and the substantial surplus of $\mathrm{N}$ in this GMS, there could be long-term problems with $\mathrm{N}$ 
Table 4. Annual nitrogen budget and balance sheet $(\mathrm{kg} \mathrm{N} /$ ha/year) for four groundcover management system treatments in an apple orchard during 2005 when nitrogen $(\mathrm{N})$ and phosphorus $(\mathrm{P})$ fertilizers were applied and 2007 without $\mathrm{N}$ or P fertilizer applications.

\begin{tabular}{|c|c|c|c|c|c|c|c|c|}
\hline & \multicolumn{8}{|c|}{ Groundcover management systems } \\
\hline & \multirow{2}{*}{\multicolumn{2}{|c|}{$\begin{array}{c}\text { PreHerb } \\
\text { (kg N/ha/year) }\end{array}$}} & \multirow{2}{*}{\multicolumn{2}{|c|}{$\frac{\text { PostHerb }}{\text { (kg N/ha/year) }}$}} & \multirow{2}{*}{\multicolumn{2}{|c|}{$\begin{array}{c}\text { Sod } \\
(\mathrm{kg} \mathrm{N} / \text { ha/year }) \\
\end{array}$}} & \multirow{2}{*}{\multicolumn{2}{|c|}{$\frac{\text { Mulch }}{\text { (kg N/ha/year) }}$}} \\
\hline & & & & & & & & \\
\hline & 2005 & 2007 & 2005 & 2007 & 2005 & 2007 & 2005 & 2007 \\
\hline \multicolumn{9}{|l|}{ A. External inputs } \\
\hline Fertilizer application & 60.0 & 0 & 60.0 & 0 & 60.0 & 0 & 60.0 & 0 \\
\hline Mulch biomass $\mathrm{N}$ & 0 & 0 & 0 & 0 & 0 & 0 & 169.2 & 84.6 \\
\hline Rainwater & 0.9 & 1.2 & 0.9 & 1.2 & 0.9 & 1.2 & 0.9 & 1.2 \\
\hline Irrigation water & 1.8 & 0.03 & 1.8 & 0.03 & 1.8 & 0.03 & 1.8 & 0.03 \\
\hline Total Inputs & 62.7 & 1.23 & 62.7 & 1.23 & 62.7 & 1.23 & $\begin{array}{l}62.7 \text { or } \\
231.9^{z}\end{array}$ & $\begin{array}{c}1.23 \text { or } \\
85.3^{z}\end{array}$ \\
\hline \multicolumn{9}{|l|}{ B. Internal fluxes } \\
\hline $\begin{array}{l}\text { Recycling surface } \\
\text { vegetation }\end{array}$ & 15.1 & 19.5 & 20.9 & 21.5 & 23.6 & 29.9 & 25.1 & 24.4 \\
\hline Soil mineralization & 11.2 & 12.3 & 13.5 & 14.1 & 14.8 & 17.2 & 17.8 & 18.9 \\
\hline Leaf litter fall & 16.4 & 10.7 & 11.6 & 14.2 & 10.3 & 17.9 & 10.3 & 15.9 \\
\hline Pruned wood & 4.1 & 11.5 & 5.6 & 13.2 & 4.8 & 14.5 & 5.2 & 14.9 \\
\hline $\begin{array}{l}\text { Total internal } \\
\text { fluxes }\end{array}$ & 46.8 & 54.0 & 51.6 & 63.0 & 53.5 & 79.5 & 58.4 & 74.1 \\
\hline \multicolumn{9}{|l|}{ C. Outputs } \\
\hline Harvested fruit ${ }^{y}$ & 69.3 & 57.3 & 82.2 & 70.3 & 54.9 & 61.0 & 80.9 & 78.0 \\
\hline Surface runoff & 4.0 & 13.5 & 3.1 & 20.8 & 1.4 & 12.8 & 1.2 & 11.1 \\
\hline $\begin{array}{l}\text { Subsurface } \\
\text { leaching }\end{array}$ & 16.1 & 5.2 & 18.9 & 5.2 & 16.1 & 5.9 & 20.9 & 7.4 \\
\hline Total outputs & 89.4 & 76.0 & 104.2 & 96.3 & 72.4 & 79.7 & 103.0 & 96.5 \\
\hline Balance $=(A+B)-C$ & 20.1 & -20.8 & 10.1 & -32.1 & 43.8 & 1.1 & $\begin{array}{l}18.1 \text { or } \\
187.3^{z}\end{array}$ & $\begin{array}{c}-21.2 \text { or } \\
62.9^{z}\end{array}$ \\
\hline
\end{tabular}

${ }^{\mathrm{z}}$ Values including calculated $\mathrm{N}$ inputs from mineralization of the mulch residue.

${ }^{\mathrm{y}}$ Fruit yield results are presented elsewhere (Atucha et al., 2011).

leaching in orchards that receive high annual inputs of compost, biomass mulch, or other permissible nutrient sources for certified organic production.

The $\mathrm{N}$ deficit for trees in the two herbicide GMSs without $\mathrm{N}$ fertilizer inputs in 2007 was caused mostly by decreased internal $\mathrm{N}$ fluxes in these two GMSs relative to Sod and Mulch. This indicates a need for $\mathrm{N}$ fertilization to meet fruit crop requirements for sustained production in orchards where herbicides are used longterm for weed control (Pires and Portela, 2005). However, the $\mathrm{N}$ deficit in these two herbicide treatments was relatively small in our study, presumably because of relatively high SOM content at this orchard, and could have been compensated with foliar applications of urea or calcium nitrate during summer cover sprays, where the potential for leaching and runoff $\mathrm{N}$ loss is relatively low compared with the losses from ground-applied $\mathrm{N}$ fertilizer applications in greater amounts.

\section{Literature Cited}

Atucha, A., I.A. Merwin, and M.G. Brown. 2011. Long-term effects of four groundcover management systems in an apple orchard. HortScience 46:1176-1183.

Brown, M.G. 2005. Design and implementation of a subsurface water observatory in an apple orchard in Upstate New York. Cornell University, Ithaca, NY. MPS project report

Chapman, K., J.B. Whittaker, and O.W. Heal. 1988. Metabolic and faunal activity in litters of tree mixtures compared with pure stands. Agr. Ecosyst. Environ. 24:33-40.
Haynes, R.J. 1980. Influence of soil management practice on the orchard agro-ecosystem. Agroecosyst. 6:3-32.

Haynes, R.J. 1988. Nutrition of apple orchards: Nutrient budgets and their relation to fertiliser requirements. Proc. Annu. Conf. Agron. Soc. New Zeal. 18:149-153.

Haynes, R.J. and K.M. Goh. 1980a. Distribution and budgets of nutrients in a commercial apple orchard. Plant Soil 56:445-457.

Haynes, R.J. and K.M. Goh. 1980b. Seasonal levels of available nutrients under grasseddown cultivated and zero-tilled orchard soil management practices. Aust. J. Soil Res. 18:363-373.

Hogue, E. and G. Neilsen. 1987. Orchard floor vegetation management. Hort. Rev. 9:377-430.

Leinfelder, M.M. 2010. Orchard soil health protocols: Evaluation and economic impacts. $\mathrm{PhD}$ thesis, Cornell University, Ithaca, NY.

Merwin, I.A. 2003a. Orchard-floor management systems, p. 303-318. In: Ferree, D.C. and I.J. Warrington (eds.). Apples: Botany, production and uses CABI Publishing, Wallingford, UK.

Merwin, I.A. 2003b. Orchard floor management, p. 195-202. In: Baugher, T.A. and S. Singha (eds.), Concise encyclopedia of temperate fruit tree. The Howarth Press, Binghamton, NY.

Merwin, I.A., J.A. Ray, T.S. Steenhuis, and J. Boll. 1996. Groundcover management systems influence fungicide and nitrate-N concentrations in leachate and runoff from a New York apple orchard. J. Amer. Soc. Hort. Sci. 121:249-257.

Merwin, I.A. and W.C. Stiles. 1994. Orchard groundcover management impacts on apple tree growth and yield, and nutrient availability and uptake. J. Amer. Soc. Hort. Sci. 119:209-215.

Merwin, I.A., W.C. Stiles, and H.M.v. Es. 1994. Orchard groundcover management impacts on soil physical properties. J. Amer. Soc. Hort. Sci. 119:216-222.

Millard, P. 1995. Internal cycling of nitrogen in trees. Acta Hort. 383:3-14 (ISHS).

Nguyen, M.L., R.J. Haynes, and K.M. Goh. 1995. Nutrient budgets and status in three pairs of conventional and alternative mixed cropping farms in Canterbury, New Zealand. Agr. Ecosyst. Environ. 52:149-162.

Oliveira, M.T. and I.A. Merwin. 2001. Soil physical conditions in a New York orchard after eight years under different groundcover management systems. Plant Soil 234:233-237.

Palmer, J.W. and G. Dryden. 2006. Fruit mineral removal rates from New Zealand apple (Malus domestica) orchards in the Nelson region. New Zeal. J. Crop Hort. 34:27-32.

Paustian, K., G.I. Agren, and E. Bosatta. 1997. Modelling litter quality effects on decomposition and soil organic matter dynamics, p. 313335. In: Cadisch, G. and K.E. Giller (eds.). Driven by nature: Plant litter quality and decomposition. CAB International, Cambridge, UK

Pires, A.L. and E. Portela. 2005. Impact of management practices on chestnut grove nutrient budgets. Acta Hort. 693:677-684.

Rossi, N., C. Ciavatta, and L.V. Antisari. 1991. Seasonal pattern of nitrate losses from cultivated soil with subsurface drainage. Water Air Soil Pollut. 60:1-10.

Sall, S.N., D. Masse, N.Y.B. Ndour, and J.L. Chotte. 2006. Does cropping modify the decomposition function and the diversity of the soil microbial community of tropical fallow soil? Appl. Soil Ecol. 31:211-219.

Shields, J.A., E.A. Paul, and W.E. Lowe. 1974. Factors influencing the stability of labelled microbial materials in soils. Soil Biol. Biochem. 6:31-37. 
Sims, J.T., R.R. Simard, and B.C. Joern. 1998. Phosphorus loss in agricultural drainage: Historical perspective and current research. J. Environ. Qual. 27:277-293.

Skroch, W.A. and J.M. Shribbs. 1986. Orchard floor management: An overview. HortScience 21:390-397.

Smith, G.S., J.G. Buwalda, and C.J. Clark. 1988. Nutrient dynamics of a kiwifruit ecosystem. Sci. Hort. 37:87-109.

Stanford, G. and E. Epstein. 1974. Nitrogen mineralization-water relations in soil. Soil Sci. Soc. Amer. J. 38:103-107.

Stanford, G. and S.J. Smith. 1972. Nitrogen mineralization potential of soils. Soil Sci. Soc. Amer. J. 36:465-472.

Stassen, P., G. Kangueehi, and J. Wooldridge. 2010. Macro and micronutrient requirements of fruit trees. SA Fruit Journal 9:44-45.

Stiles, W.C. and S.C. Reid. 1991. Orchard nutrition management. Cornell Coop. Ext. Bul. 191.

Tagliavini, M., D. Scudellazi, B. Marangoni, and M. Toselli. 1996. Nitrogen fertilization management in orchards to reconcile productivity and environmental aspects. Nutr. Cycl. Agroecosyst. 43:93-102.

Trinsoutrot, I., S. Recous, B. Bentz, M. Lineres, D. Cheneby, and B. Nicolardot. 2000. Biochemical quality of crop residues and carbon and nitrogen mineralization kinetics under nonli- miting nitrogen conditions. Soil Sci. Soc. Amer. J. 64:918-926.

Tu, C.M. 1996. Effect of selected herbicides on activities of microorganisms in soils. J. Environ. Sci. Health B 31:1201-1214.

US-EPA. 2000. Ambient water quality criteria recommendations: Rivers and streams in nutrient ecoregion VII. 12 May 2010. <http://epa. gov/waterscience/criteria/nutrient/ecoregions/ rivers/rivers_7.pdf $>$.

US-EPA. 2006. 2006 edition of the drinking water standards and health advisories. 12 Dec. 2010 $<$ http://water.epa.gov/action/advisories/drinking/ dwstandards.cfm $>$.

Van Veen, J.A., J.N. Ladd, J.K. Martin, and M. Amato. 1987. Turnover of carbon, nitrogen and phosphorus through the microbial biomass in soils incubated with 14-C-, 15N- and 32P-labelled bacterial cells. Soil Biol. Biochem. 19:559-565.

Ventura, M., N. Opstad, D. Zanotelli, F. Scandellari, M. Quartieri, and M. Tagliavini. 2005. Monitoring soil nitrogen losses through leaching in a pear orchard. Rivista di Frutticoltura e di Ortofloricoltura 67:40-44.

Wardle, D.A., G.W. Yeates, K.I. Bonner, K.S. Nicholson, and R.N. Watson. 2001. Impacts of ground vegetation management strategies in a kiwifruit orchard on the composition and functioning of the soil biota. Soil Biol. Biochem. 33:893-905.
Wardle, D.A., G.W. Yeates, R.N. Watson, and K.S. Nicholson. 1993. Response of soil microbial biomass and plant litter decomposition to weed management strategies in maize and asparagus cropping systems. Soil Biol. Biochem. 25:857868 .

Wargo, J.M., I.A. Merwin, and C.B. Watkins. 2004. Nitrogen fertilization, midsummer trunk girdling, and AVG treatments affect maturity and quality of 'Jonagold' apples. HortScience 39:493-500.

Watson, C.A. and D. Atkinson. 1999. Using nitrogen budgets to indicate nitrogen use efficiency and losses from whole farm systems: A comparison of three methodological approaches. Nutr. Cycl. Agroecosyst. 53:259-267.

Weinbaum, S.A., R.S. Johnson, and T.M. DeJong. 1992. Causes and consequences of overfertilization in orchards. HortTechnology 2:112121.

Whitmore, A.P. and J.J.R. Groot. 1997. The decomposition of sugar beet residues: Mineralization versus immobilization in contrasting soil types. Plant Soil 192:237-247.

Yao, S.R., I.A. Merwin, G.W. Bird, G.S. Abawi, and J.E. Thies. 2005. Orchard floor management practices that maintain vegetative or biomass groundcover stimulate soil microbial activity and alter soil microbial community composition. Plant Soil 271:377-389. 